medRxiv preprint doi: https://doi.org/10.1101/2022.02.10.22270821; this version posted February 15, 2022. The copyright holder for this preprint (which was not certified by peer review) is the author/funder, who has granted medRxiv a license to display the preprint in

It is made available under a CC-BY-NC-ND 4.0 International license .

\title{
MUC16 mutation is associated with tumor grade, clinical features, and prognosis
} in glioma patients

\section{Valéria Pereira Ferrer $^{1 *}$}

1. Laboratory of Cell and Molecular Biology of Tumors, Department of Cell and Molecular Biology, Biology Institute, Fluminense Federal University

*Correspondence: valeriaferrer@id.uff.br

\begin{abstract}
MUC16 is a member of the attached mucin family that encodes cancer antigen 125 (CA125), but the association of MUC16 status with grade and subtypes of glioma patients has not yet been established. Data for MUC16 mRNA expression in 37 different cancer types were considered, and genomic data from the Cancer Genome Atlas (TCGA) from 1051 LGG patients and 833 GBM patients were analyzed. LGG and GBM has low expression of MUC16, but it is frequently mutated in glioblastoma (GBM). Kaplan-Meier survival analysis, glioma subtypes, methylation, and IDH1 status were all performed. We found that mutated-MUC16 in LGG patients is associated with better prognosis considering overall survival (OS), IDH1, methylation, 1p/19q, and 10q status. Conversely, MUC16 mutation were related with worse prognosis in GBM patients upon analyzing those same parameters. Therefore, MUC16 mutations may assist in glioma diagnosis and prognosis and should be further studied in this tumor type.
\end{abstract}

Keywords: mucin, MUC16, mutation, gliomas, biomarker 


\section{INTRODUCTION}

Gliomas are tumors derived from glial cells and glial precursor cells and one of the most frequent and malignant tumors among the primary adult brain tumors ${ }^{1}$. Lowgrade gliomas (LGG) are slow-growing tumors classified by WHO (World Health Organization) as grade I or II (diffuse gliomas) (Wang and Mehta, 2019) or III (anaplastic astrocytomas, $\left.{ }^{3}\right)$. Grade I applies to tumors with a low proliferative rate that can potentially be cured following surgical resection. Grade II neoplasms are generally infiltrative despite having a low-level proliferative rate. Some types may progress to higher grades of malignancy. WHO grade III includes nuclear atypia and abrupt mitotic activity; these patients must receive adjuvant radiation and/or chemotherapy ${ }^{4}$. LGG predominantly affects young adults (until 40 years-old); they are composed of various distinct tumors based on histopathology 5 . More recently, the WHO reclassified LGG by combining histopathologic features with molecular markers such as isocitrate dehydrogenase (IDH) mutations and $1 \mathrm{p} / 19 \mathrm{q}$ codeletion status. In this classification, prognosis is more strongly associated with molecular diagnostic characteristics ${ }^{6}$. Patients with LGG generally have a favorable prognosis ${ }^{2}$.

In contrast, glioblastomas (WHO grade IV) are very deadly tumors ${ }^{4}$ and feature high rates of proliferation and invasiveness. They have high heterogeneity both inter and intra-tumor, high angiogenesis rates, and resistance to therapies ${ }^{7,8}$. The overall survival rate (OS) after diagnosis is only 12-15 months on average ${ }^{9}$. Thus, novel therapies to improve quality and expectation of life as well as new biomarkers to improve diagnosis and prognosis are urgently needed for this cancer type ${ }^{9,10}$.

MUC16 is a membrane-attached member of the mucin family that is expressed by some normal cells such as corneal, ovarian, and bronchial epithelial cells ${ }^{11-14}$. A transmembrane region of these glycoproteins' anchors in the cell membrane, and MUC16 can be released from the cell surface by proteolytic cleavage from some proteases ${ }^{15}$. The released domain of MUC16 has a very similar molecular weight as the intact molecule ${ }^{14}$. MUC16 is a very glycosylated mucin, and these post-translational modifications near the site of cleavage regulates release of these glycoproteins' ectodomains ${ }^{16,17}$. Molecular cloning of MUC16 revealed that this protein has a molecular weight of 3-5 $\mathrm{MDa}^{18}$. Like other mucins, MUC16 is composed of a tandem repeat region sandwiched between the C-terminus, attached at membrane, and N-terminal domains (Figure 1A). CA-125 is a 
repetitive peptide epitope of MUC16 composed of 156 amino acids (aa) ${ }^{14,17}$. The MUC16 gene is present in the short arm of chromosome 19 (at 19p13.2) and is composed of 84 exons encoding for a 22,152 amino acid protein. This gene is susceptible to substitutions, insertions, deletions, copy number variation (CNV) gain and losses, and different methylation patterns (Figure 1B) depending on the tissue. There is no clear consensus regarding the MUC16 promoter sequence to date ${ }^{19}$.

MUC16/CA-125 expression has been correlated to progression and clinical status in patients with breast ${ }^{20,21}$, ovarian ${ }^{22,23}$, and pancreas ${ }^{24,25}$. Mutated MUC16 has already been observed and explored clinically in malignancies such as endometrium ${ }^{26}$, lung ${ }^{27}$, melanoma ${ }^{28}$, and gastric cancers ${ }^{29}$. MUC16 has also gained attention as a novel target to therapy in several cancer types ${ }^{14,30}$.

Some members of the mucin family have been detected in gliomas ${ }^{31-33}$. However, to date, MUC16 mutations have not yet been explored in these tumors. Here, for the first time, we demonstrate the proof-of-principle that the MUC16 mutation has value in glioma diagnosis and prognosis. We related MUC16 mutations to molecular types and subtypes of gliomas and associated mutated MUC16 to the prognosis of these tumors. Therefore, we open an avenue and suggest that MUC16 mutations could be further studied and explored in glioma patients. 
medRxiv preprint doi: https://doi.org/10.1101/2022.02.10.22270821; this version posted February 15, 2022. The copyright holder for this preprint (which was not certified by peer review) is the author/funder, who has granted medRxiv a license to display the preprint in

It is made available under a CC-BY-NC-ND 4.0 International license.

\section{MATERIALS AND METHODS}

\section{Source of data analysis and mutation frequency counting}

Data for MUC16 differential mRNA analysis from the 37 different tumors were obtained at the Broad Institute of Massachusetts Institute of Technology (MIT) \& Harvard Portal (http://firebrowse.org/viewGene.html). Data from the TCGA database for both LGG and GBM samples were obtained from the cBio Portal (www.cbioportal.org) ${ }^{34,35}$.

LGG analysis selected the following data: 530 samples from TCGA Brain LGG from

GDAC

firehose (https://gdac.broadinstitute.org/runs/stddata_2016_01_28/data/LGG/20160128/)； 514 samples from Brain LGG TCGA PanCancer Data ${ }^{36-45}$; 61 samples from a whole exome sequence study ${ }^{46}$; and 1102 samples from another whole exome sequencing work ${ }^{47}$. After refinement to enrich the analysis in WHO grade III samples and compare with GBM, we selected 312 oligodendrogliomas specimens (14.0\%); 212 astrocytomas (12.7\%); 277 oligoastrocytomas (12.4\%); 141 anaplastic astrocytomas (6.3\%); and 78 anaplastic oligoastrocytomas (3.5\%). We excluded 1,123 diffuse gliomas (50.4\%); 13 glioblastomas $(0.6 \%)$; and 1 LGG (NOS, <0.1\%) from the analysis. This led to 1,051 patients and 1,090 LGG samples.

The following were selected for GBM analysis: 42 samples from a whole-genome sequence study ${ }^{48}$; 543 samples from a whole-exome and whole genome sequence analysis ${ }^{49}$; 206 samples from a targeting sequences from primary GBM in the TCGA ${ }^{50}$; 619 TCGA samples from the GDAC firehose (https://gdac.broadinstitute.org/runs/stddata_2016_01_28/data/GBM/20160128/); and 592 GBM from the TCGA PanCancer database (https://www.cell.com/pbassets/consortium/pancanceratlas/pancani3/index.html). Of these 2,036 samples, a refinement was performed to select samples classified as "glioblastoma" and "glioblastoma multiforme" (41.2\%) excluding the samples classified as "gliomas" (58.7\%). This refinement led to the 833 patients and 840 samples analyzed here.

The analysis of gene mutation and its frequency were analyzed via cBio Portal: Of the 1,090 LGG samples, 848 were profiled. Of the 840 GBM samples, 520 were profiled. 


\section{Overall survival analysis}

Overall survival data was downloaded from cBio Portal for the 848 profiled LGG samples and for the 520 profiled GBM samples. Survival data was censored until the last date that the patient was known to be alive. The samples were first segregated in a MUC16 mutated gene or MUC16 wild-type gene. Survival functions were estimated using Kaplan-Meier method and compared using a log-rank (Mantel-Cox) test in GraphPad Prism software (version 5). The median survival time was calculated as the smallest survival time for which the survivor function is equal or less than $50 \%$. After, a derivative analysis of survival function was performed, only data with more than $50 \%$ probability of survival was used for LGG patients or less than $50 \%$ of probability of survival for GBM. A new survival curve was obtained for this analysis. Next, data from GBM patients carrying PTEN, TP53, TTN, EGFR, and MUC16 mutations were used to create a KaplanMeier survival curve and log-rank (Mantel-Cox) test. This survival graph was created in the cBio Portal with overlap count with mutation analysis.

\section{Clinical features of glioma patients}

Clinical data for the IDH1 status, 1p/19q co-deletion, methylation patterns, and 10q deletion status were obtained from the cBio Portal. Clinical information from 160 GBM samples (150 patients) and from 23 LGG samples (23 patients) were also analyzed. Percentage bar graphs were obtained from these parameters after analyzing the data and using the cBio Portal. 
medRxiv preprint doi: https://doi.org/10.1101/2022.02.10.22270821; this version posted February 15, 2022. The copyright holder for this preprint (which was not certified by peer review) is the author/funder, who has granted medRxiv a license to display the preprint in

It is made available under a CC-BY-NC-ND 4.0 International license .

\section{RESULTS}

Mutated-MUC16 is within the most frequent genes in GBM but not in the LGG patients

Analysis of 37 different types of tumors indicated that both LGG and GBM have very low MUC16 mRNA expression. LGG (194 samples) have the lowest expression with a median of $-0.904(-1.42 ; 0.205)$; GBM (33 samples) has the fourth lowest expression with a median of $-0.626(-1.04 ; 0.384)$. There was no difference between the expression of LGG+GBM specimens and normal tissue samples (Figure 2A).

In turn, when we have analyzed the frequency of MUC16 mutation in LGG patients (848 samples), the mutated-MUC16 is not one of the top ten most frequent genes (IDH1 78.3\%; TP53 51.7\%; ATRX 41.3\%; CIC 19.5\% TTN 11.1\%; FUBP1 9.1\%; and NCOA6, RPL21, OR10AG1, and ZKSCAN4 8.3\%) with a frequency of 6.3\% (Figure 2B). However, MUC16 is the fifth most frequent gene in GBM patients (520 samples) with a $14.9 \%$ frequency. It is only above PTEN (32.3\%); TP53 (30.6\%); TTN (25.4\%); and EGFR (21.2\%) (Figure 2B).

\section{Mutated MUC16 patients have better OS in LGG and worse OS in GBM versus wild-type counterparts}

We questioned whether MUC16 mutations are associated with the OS of glioma patients. We analyzed 45 censored patients (LGG patients) with MUC16 mutations versus 731 censored patients with wild-type MUC16. The analysis showed that the mutatedMUC16 is associated with better prognosis in LGG patients (Figure 3A). The median survival in LGG MUC16 wild-type patients was 79.93 months, and all mutated-MUC16 patients had more than a 50\% probability of survival over the time observed $(p=0.0609)$. We then compared the same 45 censored patients containing MUC16 mutations with the 572 wild-type MUC16 patients with more than $50 \%$ of probability to survive within the time observed (Figure 3B). For this analysis, the OS was significantly higher in patients with the MUC16 mutation ( $\mathrm{p}=0.0005)$ versus LGG patients with wild-type MUC16 who have had a median survival of 57.88 months.

In turn, we analyzed 12 censored GBM patients with MUC16 mutations versus 133 censored patients with wild-type MUC16. Contrary to the finding in LGG patients, GBM 
medRxiv preprint doi: https://doi.org/10.1101/2022.02.10.22270821; this version posted February 15, 2022. The copyright holder for this preprint (which was not certified by peer review) is the author/funder, who has granted medRxiv a license to display the preprint in

It is made available under a CC-BY-NC-ND 4.0 International license .

patients with a MUC16 mutation have worse prognosis than MUC16-wild-type patients (Figure 3C): There was a median survival of 12.33 months in mutated patients versus 14.53 months in other patients $(\mathrm{p}=0.0651)$. We next analyzed patients with less than $50 \%$ probability of survival, and identified six mutated MUC16 patients and 55 MUC16 wild-type patients. The OS difference was significant $(\mathrm{p}=0.0168)$ with median survival times of 20.6 and 24.2 months, respectively (Figure 3D).

\section{Patients with a mutated MUC16 gene have a worse OS among some clinically relevant mutated genes in GBM}

Among the top five most frequently mutated genes found in GBM (EGFR, MUC16, PTEN, TP53 and TTN), patients with a mutated MUC16 have the worse OS ( $p=0.0074)$ (Figure 4A) with a median survival of 12.33 months followed by mutated EGFR (13.78 months), TTN (14.07 months), PTEN (15.02 months), and TP53 (19.82 months) (Figure 4B). We counted the overlap of the top five mutated genes in GBM patients ( $N=173$ ) (Figure 4C) and observed that GBM patients bearing only P53 mutation represented $32.36 \%$ of patients $(\mathrm{N}=56)$ followed by PTEN mutations only $(30.63 \%, \mathrm{~N}=53)$; EGFR only $(19.07 \%, \mathrm{~N}=33)$; TTN $(16.76 \%, \mathrm{~N}=29)$; and MUC16 only $(10.40 \%, \mathrm{~N}=18)$. Our analysis showed that $4.6 \%$ of GBM patients have MUC16 plus EGFR mutations $(\mathrm{N}=8)$, $4.0 \%$ of patients have MUC16 and TTN mutations $(\mathrm{N}=7), 2.89 \%$ of patients overlap MUC16 and PTEN mutations (N=5), and 2.31\% have MUC16, PTEN, and TTN mutated genes or MUC16, TP53, and TTN mutations $(\mathrm{N}=4)$. Other combinatory profiles of these mutations were also seen $(8.67 \% ; \mathrm{N}=15)$.

\section{MUC16 status correlates to clinical features of glioma patients}

We next analyzed some other clinical parameters beyond OS. Data from 23 LGG patients (23 samples) and 155 GBM patients (160 samples) containing EGFR, MUC16, PTEN, TP53, and PI3K mutations were analyzed in terms of glioma type and subtype, MGMT and G-CIMP methylation status, and 1p/19q and 10q deletion. PIK3 is another clinically relevant and frequently mutated gene in GBM (Figure 2B). Figure 5A shows that $\sim 90 \%$ of LGG samples with EGFR or PTEN mutations have wild-type IDH1 while more than $60 \%$ of LGG samples with mutated PIK3 have IDH1 mutation and 1p/19q 
codeletion status. Among LGG mutated MUC16 patients, more than $85 \%$ of samples have an IDH1 mutation and a 1p/19q codeletion; the most of the mutated genes analyzed. All GBM samples with mutated MUC16 or with mutated PTEN have wild-type IDH1 followed by mutated EGFR (98\%), PIK3 (90\%), and TP53 (75\%). We classified the GBM samples into recurrent or not recurrent samples (Figure 5B), and the mutated MUC16 has the second highest number of recurrency with $\sim 4 \%$ of samples. Mutated PIK3 is seen in $\sim 13 \%$ followed by PTEN ( 3\%) and EGFR or TP53 ( 1\%).

To classify samples based on MGMT methylation status (Figure 5C), we next obtained data from LGG-mutated MUC16 and TP53 samples. We found that $100 \%$ of mutated MUC16 samples have methylated MGMT promoter versus 65\% of mutated TP53 samples. For the GBM samples we found the cytosine-phosphate-guanine (CpG) island methylator phenotype (G-CIMP) (Figure 5C); 100\% of mutated MUC16 or mutated PTEN GBM samples do not have the G-CIMP phenotype. In the other GBM samples a percentage have a G-CIMP methylation status: TP53 ( 25\%), PIK3 ( 10\%), and $\operatorname{EGFR}(\sim 2 \%)$.

The chromosomal arm 10q status was studied while comparing LGG and GBM samples. For the same mutation, the percentage of chromosome 10q deletions increased significantly in GBM samples except for PTEN samples that reduced from 100\% in LGG to $95 \%$ of GBM samples analyzed (Figure 5D). The mutated EGFR samples showed that the number of $10 \mathrm{q}$ deletions increased from $88 \%$ in LGG samples to $100 \%$ in GBM samples. The mutated MUC16 samples have a deletion that increased from 15\% to $95 \%$ in LGG and GBM samples, respectively. The mutated PI3K specimens increased from $10 \%$ to $90 \%$ and from $5 \%$ to $65 \%$ in mutated TP53 samples. Therefore, patients containing MUC16 and PI3K mutations have the highest increase in 10q deletions among LGG and GBM samples. 


\section{DISCUSSION}

Gliomas account for $80 \%$ of malignant brain tumors ${ }^{51}$ and can be classified into LGG and high-grade gliomas (HGG), GBM. Here, LGG comprises a very diverse group of gliomas including diffuse low-grade gliomas (WHO grade II) and WHO grade III gliomas ${ }^{6}$. Although LGG patients have better survival than GBM patients (18 months versus $\sim 7.3$ years $)^{52}$, LGG can progress to GBM in some cases ${ }^{47}$. In addition, despite the decades of research on GBM, limited progress has been made to increase the quality and expectancy of life in these patients ${ }^{53}$. In this context and considering the high variability intra- and inter-evaluator on precise diagnostic based on histology alone the classification of brain tumors was revisited in 2016, and molecular criteria have been included for histopathological features ${ }^{6,54}$. This new classification shows better compatibility between the diagnostic and the clinical evolution of patients and has opened new therapeutic possibilities. Based on a retrospective analysis of TCGA data, it has been identified important genetic mutations that assist in more precise glioma diagnosis and prognosis than histology. This includes mutations in IDH, ATRX, and TERT promoters in combination with chromosomal arm deletions of $1 p$ and $19 q$ among other specificities 55,56 .

The expression of MUC16 (the longest member of mucin family) has been clinically explored in several types of cancer for many years ${ }^{30,57-60}$. The classical example is ovarian cancer where it has already been used and studied for four decades 14,61,62. MUC16 is often one of the most frequently mutated genes in tumors ${ }^{28,63,64}$ and is often associated with increased tumor progression ${ }^{65-69}$. However, MUC16 expression and mutation have not yet been further studied in glioma patients. Here, for the first time, we evaluated MUC16 mutation status in both LGG and GBM cohorts and correlated these with glioma grade, subtypes, and clinical outcomes.

By analyzing the expression of MUC16 in different tumors, we verified that both LGG and GBM have very low MUC16 mRNA amount; LGG has the lowest expression of all tumors analyzed. We presume that this membrane-bound mucin has not gained much attention in this type of tumor due to this low expression unlike what occurs in other types of tumors such as ovarian, endometrial, and mesothelioma cancers ${ }^{21,70,71}$ where we have observed high MUC16 mRNA expression. The expression of membrane-attached mucins like MUC1 has been detected in both epithelial and non-epithelial tumor cells including astrocytomas and neuroblastomas for over twenty years ${ }^{32}$. The analysis of other 
medRxiv preprint doi: https://doi.org/10.1101/2022.02.10.22270821; this version posted February 15, 2022. The copyright holder for this preprint (which was not certified by peer review) is the author/funder, who has granted medRxiv a license to display the preprint in It is made available under a CC-BY-NC-ND 4.0 International license .

membrane-attached mucin, e.g., MUC15, has shown that its levels of mRNA and protein in glioma tissues are significantly increased versus non-cancerous brain tissues. MUC15 levels have been positively correlated with clinical stages (I, II, III vs. IV) ( $p<0.001)$ in glioma patients, and the mean value is higher in grade IV, GBM tissues $(\mathrm{p}<0.01)^{72}$. Additionally, MUC4 expression has been shown to be elevated in both GBM tissues and cell lines. The ectopic expression of MUC4 significantly enhanced GBM cell proliferation, migration, and invasion, and these processes were reverted when MUC4 was knocked down in GBM cells. Interesting, the participation of MUC4 in these events is partly associated with the expression of EGFR ${ }^{73}$. Despite MUC16's low mRNA expression, we have been interested in analyzing the mutation status of this gene in both LGG and GBM while searching for new diagnostic and prognostic biomarkers as well as new therapeutic targets.

Mutations in MUC16 are more common in GBM than LGG. Therefore, we hypothesized that it may be associated with progression and aggressiveness in gliomas as observed in other membrane-attached mucins, e.g., MUC1 and MUC15. Corroborating our findings, Xiao et al. (2021) ${ }^{74}$ studied aging related genes as prognostic biomarkers for patients in gliomas and found that the frequency of mutations for PIK3CA, MUC16, and TTN are significantly higher in high-risk glioma cases (TTN, 26\% versus 7\%; MUC16, 16\% versus 8\%; PIK3CA, 10\% versus 3\%). Additionally, using multipoint sequencing for 11 patients Yang et al. (2019) ${ }^{75}$ found that MUC16 is the most frequent gene found in GBM. The Chinese Glioma Genome Atlas GBM database shows that MUC16 mutations are higher in recurrent GBM. Here, we show that the MUC16 mutation frequency is associated with grade and malignancy in gliomas.

The MUC16 mutation status is a good prognostic biomarker in LGG patients. Similar results have been observed in other tumors. MUC16 mutations are associated with improved OS in the endometrial tumors $(\mathrm{p}=0.0003)^{26}$, non-small cell lunger cancer (NSCLC) $(p=0.04)$, melanoma $(p=0.02)^{76}$, and gastric cancer cohorts ${ }^{77}$. Conversely, GBM patients with MUC16 mutations have a worse prognosis. Retrospective genome analysis agrees with our findings and demonstrated a similar result: GBM patients with a MUC16 gene mutation have worse OS outcomes than wild-type patients $(p=0.0164)^{75}$. Here, we highlight that this result has come from GBM cohorts with less than $50 \%$ of probability to survive. High MUC15 expressing patients correlated with a shorter survival time (29.2 \pm 6.7 months) than the MUC15 low expression cohort (53.5 \pm 7.2 months) ${ }^{72}$. 
Here, GBM patients carrying a MUC16 mutation have a worse OS among the five clinically important genes analyzed. How these MUC16 mutations culminate in the aggressive phenotype seen in GBM patients need further study.

We further analyzed the clinical aspects of glioma patients beyond OS: IDH1 status, methylation patterns, and deletion status of chromosome arms 1p/19q and 10q. Most LGG patients (65-90\%) carry on IDH mutation ${ }^{78,79}$. This type of mutation has been correlated with better prognosis in glioma cohorts who have presented better progressionfree survival independent of the treatment ${ }^{54,80}$. However, most primary GBM have wildtype IDH1, and most LGG that progresses to GBM have wild-type IDH and are aggressive tumors with worse prognosis. The presence of $1 \mathrm{p} / 19 \mathrm{q}$ co-deletion is a strong and predictive biomarker in LGG patients ${ }^{6,54}$.

Anaplastic oligodendroglioma and oligoastrocytoma are associated with longer OS ( 7.3 versus 2.7 years) when these patients have been treated with radiotherapy alone or procarbazine, lomustine, vincristine (14.7 versus 2.7 years) ${ }^{81,82}$. Here, we observed that the MUC16 mutation correlates with IDH1 and 1p/19q status. Most LGG MUC16 mutation patients have IDH mutations and $1 \mathrm{p} / 19 \mathrm{q}$ deletions, thus presenting better OS than wild-type patients. The infiltrating level of immune cells and the expression of immune checkpoint genes significantly lowers 1p/19q codeletion LGGs versus 1p/19q non-codeletion patients ${ }^{83}$. All GBM patients carrying a MUC16 mutation have wild-type IDH with worse prognosis than non-MUC16 mutated patients. When analyzing LGG IDH1 mutated patients with high or low mutational burden, MUC16 is one of the top 10 mutated genes in the LGG IDH1 mutated patients with high mutational burden but not in the low mutational burden cohort. There were no differences in OS by analyzing MUC16 between LGG patients with high and low IDH1 mutation burden ${ }^{52}$. We therefore suggest that the analysis of MUC16 mutations can be a confirmative biomarker of IDH1 and $1 \mathrm{p} / 19 \mathrm{q}$ status, thus contributing to more precise diagnosis and prognosis in gliomas.

IDH1 mutations in gliomas have led to an increase in genome-wide methylation. This has been associated with proneural glioma subtypes with patients having a better survival outcome. A very small group of IDH-mutated gliomas lack DNA hypermethylation and have poor survival ${ }^{54,84,85}$. Thus, our results demonstrated that all LGG MUC16 mutated patients have MGMT methylation status while all MUC16 mutated GBM patients have non-G-CIMP methylation. Methylation of the MGMT promoter in the $\mathrm{CpG}$-rich region is present in $\sim 40 \%$ of all GBMs and culminates in 
decreased expression of the MGMT protein — an enzyme that reverts the DNA alkylating effect of temozolomide (TMZ) ${ }^{86,87}$. Higher levels of MGMT promoter methylation, thus predicts longer survival in IDH-mutated and wild-type IDH glioma patients ${ }^{88,89}$. Among people receiving radiotherapy and TMZ, MGMT promoter methylation is associated with improved median survival of 21.7 months versus 12.7 months for patients with unmethylated tumors ${ }^{90}$. MGMT promoter methylation is useful as a prognostic and predictive marker, but it cannot define distinct diagnostic subtypes of gliomas per se ${ }^{54}$; thus, MUC16 status might be useful to improve diagnostic and predictive response to therapy in these patients.

Loss of heterozygosity ( $\mathrm{LOH}$ ) in 10q is common in gliomas and is associated with HGG; it is a negative prognostic marker ${ }^{91}$. The median OS for patients with or without loss of $10 \mathrm{q}$ is 6.6 years versus 16.7 years $(\mathrm{p}=0.009)$, respectively ${ }^{89}$. In our results, most LGG patients with MUC16, PIK3, and TP53 mutations have the 10q chromosome arm intact, which is suggestive of good prognosis and corroborates our other results. The deletion of $10 \mathrm{q}$ seems to be an important mechanism to progression of LGG to HGG: All GBM patients have had an increase in the deletion of this chromosome.

MGMT is located at the chromosome 10q26.3 site. Chromosome 10q LOH has a MGMT locus loss as observed in $9 \%, 56 \%$, and $75 \%$ of grade II, grade III, and grade IV gliomas, respectively, thus confirming a positive correlation with tumor grade $(\mathrm{p}=$ 0.0002) ${ }^{92}$. However, there are also differences when gliomas have been classified in MGMT methylation levels according to $10 \mathrm{q} \mathrm{LOH}$. Therefore, the lack of one MGMT allele does not affect the methylation of the remaining allele ${ }^{89}$. We thus suggest that the measurement of frequency of the MUC16 mutation could assist in the classification of patients in LGG or GBM in combination with the 10q deletion status.

In summary, the MUC16 mutation status could assist in the diagnosis, prognosis and predictive therapy of glioma patients, thus complementing and corroborating the classification and subclassification information given by IDH1 mutations, G-CIMP methylation status, and the 10q chromosome arm deletion in glioma patients. Recently, a more detailed understanding of molecular alterations within gliomas have allowed a refinement of diagnostic and prognostic biomarkers with the ability to utilize effective targeted therapies in molecularly defined glioma subtypes ${ }^{54}$. 
MUC16 can modulate immune cells in tumors via different approaches ${ }^{94}$. It is a huge structure with an overall negative charge due to the presence of terminal sialic acid residues ${ }^{95}$. Thus, MUC16 may inhibit further interactions between NK (natural killer) and cancer cells. NK cells express inhibitory receptors on their cell surface such as Siglec7 and Siglec-9, e.g., inhibiting the NK cell cytolytic response ${ }^{14,95-97}$. Additionally, MUC16 binding Siglecs mask toll-like receptors (TLR) on dendritic cells (DC), thus promoting an immature phenotype in these cells that can reduces T cell effector functions ${ }^{94}$. Tumoral mucin-mediated ligation (CA-125 and TAG-72) to the mannose receptor on infiltrating tumor-associated macrophages (TAM) may contribute to their immune suppressive phenotype ${ }^{98}$. Moreover, MUC16 interacts or aggregates with neutrophils, macrophages, and platelets thus conferring protection to cancer cells during its dissemination that facilitates their spread ${ }^{94}$.

In addition, MUC16 has been implicated in cancer cell signaling ${ }^{30}$. Its knockdown has induced epithelial-mesenchymal transition (EMT) in ovarian cell lines and activation of EGFR signaling via AKT and ERK1/2 ${ }^{99}$. The knockdown of MUC16 expression contributed to drug resistance in ovarian cell lines ${ }^{20}$. Our results have shown low MUC16 mRNA expression in both LGG and GBM patients. This low expression might also favor EMT and drug resistance in these glioma cells.

Immune checkpoint inhibitors (ICI) have been used successfully as therapeutic targets in several tumor types such as melanoma and NSCLC ${ }^{100,101}$. However, an enhanced response has not been reported in ICI-treated hepatocellular carcinoma (HCC) patients. HCC patients presenting better survival have elevated tumor mutation load ( $\mathrm{p}<$ $0.05)$ and higher mutation rates of immune response genes such as MUC16 ( $<0.05)$. The discovery of this HCC leads to better survival subtypes might aid with HCC immunotherapy predictions ${ }^{102}$. Related to ICI therapy in HCC, MUC16 mutations have been associated with greater response rates in the NSCLC and the melanoma cohort (both $\mathrm{p}=0.03$ ). It may be a promising biomarker for guiding immunotherapeutic response in these patients ${ }^{76}$. This pan-cancer study reported that patients bearing MUC16 mutations had a higher tumor mutational burden and neoantigen load than those without mutations. The tumor immune microenvironment molecules were over-represented in MUC16mutated tumors versus wild-type tumors $(\mathrm{p}<0.001)$. Genes regarding the immune response have been enriched in MUC16-mutated tumors $(p<0.001)^{76}$. Conversely, a 
medRxiv preprint doi: https://doi.org/10.1101/2022.02.10.22270821; this version posted February 15, 2022. The copyright holder for this preprint (which was not certified by peer review) is the author/funder, who has granted medRxiv a license to display the preprint in It is made available under a CC-BY-NC-ND 4.0 International license .

recent study with breast cancer patients resistant to CDK4/6 inhibitors found that mutations in MUC4 and MUC16 genes were related to the treatment resistance ${ }^{104}$.

In GBM, a recent clinical trial using anti-PD1 (program cell death protein 1) showed that only $8 \%$ of patients have an effective response in the recurrent group ${ }^{105}$. Genomic and transcriptomic analysis revealed a significant enrichment of PTEN mutations associated with immunosuppressive expression signatures in non-responders' patients, and an enrichment of MAPK pathway alterations (BRAF and PTPN11) among the responders ${ }^{48}$. We suggest that MUC16 might be a possible new biomarker to monitor response to ICI in glioma patients. Further studies are still necessary. 
medRxiv preprint doi: https://doi.org/10.1101/2022.02.10.22270821; this version posted February 15, 2022. The copyright holder for this preprint (which was not certified by peer review) is the author/funder, who has granted medRxiv a license to display the preprint in

It is made available under a CC-BY-NC-ND 4.0 International license .

\section{CONCLUSION}

We conclude that gliomas have low MUC16 mRNA expression, and GBM patients have a higher frequency of MUC16 mutations versus LGG patients. Overall, these LGGMUC16 mutated patients have clinical features indicating good prognosis: mutated IDH1, $1 \mathrm{p} / 19 \mathrm{q}$ chromosome arm co-deletion, high methylation patterns, low 10q deletion status, and better OS than the MUC16 wild-type patients. In turn, GBM patients carrying mutated MUC16 often have wild-type IDH1, non-G-CIMP methylation, 10q arm deletion, high rates of recurrency, and worse OS than the non-mutated patients. These clinical characteristics all predict a bad prognosis. We suggest that MUC16 gene mutation can be a new biomarker in LGG and GBM cohorts, thus assisting others classical biomarkers in finding gliomas subtypes and contributing to diagnosis, prognosis, and predicting response to therapy. We presented here a proof-of-principle conception that highlights this avenue for future work using MUC16 gene mutations as a glioma biomarker.

\section{ACKNOWLEDGMENTS}

The author thanks all the researchers who have contributed to the TCGA data. Acknowledgements to the researchers who built and maintained the online portals used in this work: cBio Portal; firebrowse (Broad Institute); and COSMIC online version 95. Special thanks to Dr. Micaela Morgado and Prof. Daniel Carson from Rice University (Houston, Texas) for the introduction to MUC16 biology in cancer.

\section{AUTHOR CONTRIBUTIONS}

V.F. screened and takes responsibility for the integrity of the data and the accuracy of the data analysis, performed bioinformatic analysis and wrote the manuscript.

\section{DECLARATION OF INTERESTS}

The author declares no competing interests. 


\section{FIGURE LEGENDS}

Figure 1. Structure of MUC16. (A) Schematic protein. MUC16 is a huge glycoprotein that contains 16 sperm protein, enterokinase, and agrin (SEA) modules and 156 amino acids (AA) in 60+ tandem repeats sandwiched by the MUC16-C and Nterminal (NT) domains. The C-terminal portion consists of the transmembrane (TM) region and a 32-residue cytoplasmic tail (CT). The MUC16 cleavage site occurs in the 12 extracellular amino acids domain proximal to the TM domain. The NT subunit consists of a heavily O-glycosylated mucin region. (B) Gene view histogram: histogram based on data from primary tissues (COSMIC online version 95) representing the overall frequency of substitutions and gene modifications found in MUC16 among different tissues. The MUC16 gene contains 43,484 base pairs (bp) encoding a 22,152 aa protein.

Figure 2. MUC16 mutation frequency but not MUC16 mRNA levels are related to glioma grade. (A) MUC16 differential plot. MUC16 mRNA differential levels in different tumor types. Ovarian and uterine cancers have the highest MUC16 mRNA levels while gliomas and kidney cancer have the lowest rates. LGG has the lowest levels. (B) List of the topmost frequent genes in LGG and GBM samples: MUC16 is within the top five most frequent gene in GBM samples, but it is not in the top ten most frequent in LGG. \#Mut = total number of mutations; \# = number of samples with one or more mutations; freq = frequency; OV = ovarian serous cystadenocarcinoma; $\mathrm{UCEC}=$ uterine corpus endometrial carcinoma; $\mathrm{MESO}=$ mesothelioma; $\mathrm{CESC}=$ cervical squamous cell carcinoma and endocervical adenocarcinoma; $\mathrm{PAAD}=$ pancreatic adenocarcinoma; LUAD = lung adenocarcinoma; UCS = uterine carcinosarcoma; HNSC = head-neck squamous cell carcinoma; ESCA = esophageal carcinoma; LUSC = lung squamous cell carcinoma; TGCT = testicular germ cell tumors; BRCA = breast invasive cancinoma; THCA = thyroid carcinoma; STES = esophagogastric cancer; BLCA = bladder urothelial carcinoma; STAD = stomach adenocarcinoma; DLBC = diffuse large B-cell lymphoma; PRAD = prostate adenocarcinoma; LAML = acute myeloid leukemia; READ = rectum adenocarcinoma; $\mathrm{CHOL}=$ cholangiocarcinoma; $\mathrm{COADREAD}=$ colorectal adenocarcinoma; $\mathrm{COAD}=$ colon adenocarcinoma; $\mathrm{KIRC}=$ kidney renal clear cell carcinoma; KIPAN = pan-kidney cohort; KIRP = kidney renal papillary cell carcinoma; $\mathrm{SARC}=$ sarcoma $; \mathrm{THYM}=$ thymoma $; \mathrm{SKCM}=$ skin cutaneous melanoma $; \mathrm{UVM}=$ uveal Melanoma; LIHC = liver hepatocellular carcinoma; ACC = adrenocortical carcinoma; 
PCPG = pheochromocytoma and paraganglioma; GBM = glioblastoma; $\mathrm{KICH}=$ kidney chromophobe; GBMLGG = glioblastoma plus low-grade glioma; LGG = low-grade glioma. IDH1 = isocitrate dehydrogenase 1; TP53 = tumor protein 53; ATRX = alphathalassemia/mental retardation syndrome, nondeletion type, $\mathrm{X}$-linked ; CIC = capicua transcriptional repressor; TTN = titina; FUBP1 = far upstream element binding protein 1; NCOA6 = nuclear receptor coactivator 6; RPL21 = ribosomal protein L21; OR10AG1 = olfactory receptor family 10 subfamily AG member 1; ZKSCAN4 = zinc finger with KRAB and SCAN domains 4; PTEN = phosphatase and tensin homolog; EGFR = epidermal growth factor receptor; FLG = profilaggrin; NF1 = neurofibromatosis type 1; RYR2 = ryanodine receptor 2; PIK3R1 = phosphoinositide-3-kinase regulatory subunit $1 ;$ SPAT1 = spermatogenesis associated 1.

Figure 3. MUC16 mutations are associated with good prognosis in LGG patients and bad prognosis in GBM patients. LGG and GBM patients with mutated MUC16 and wild-type MUC16 in OS curve analysis. (A) LGG patients with a MUC16 mutation have better prognosis than their counterparts, but this is no significant ( $p=0.0609)$. (B) In turn, among LGG patients who presented with more than $50 \%$ of probability to survive, those bearing a MUC16 mutation have better prognosis than wild-type MUC16 (*p = 0.0005). (C) Conversely, analysis of all GBM patients shows that patients bearing a MUC16 mutation have a worse prognosis than others. However, this result was not statistically significant ( $\mathrm{p}=0.0651$ ). (D) When we have selected the GBM patients with less than $50 \%$ of chance to survive and reanalyzed the OS among them, we found that patients with mutated MUC16 have worse prognosis than wild-type patients (*p = $0.0168)$

Figure 4. GBM patients bearing MUC16 mutation have the worse OS among clinically important mutated genes. (A) Analysis of the OS curve among GBM patients carrying EGFR, MUC16, PTEN, TP53, and TTN mutations. A worse OS is observed in patients with a MUC16 mutation followed by GBM patients with EGFR, TTN, PTEN, and TP53 mutations ( $\left.{ }^{*} \mathrm{p}=0.0074\right)$. (B) Table describing the median of OS as a function of months among the five genes analyzed. (C) Graphic showing the counting of patients who overlap or not overlap the five mutations in analysis. Patients with MUC16 mutation 
medRxiv preprint doi: https://doi.org/10.1101/2022.02.10.22270821; this version posted February 15, 2022. The copyright holder for this preprint (which was not certified by peer review) is the author/funder, who has granted medRxiv a license to display the preprint in

It is made available under a CC-BY-NC-ND 4.0 International license.

only have $10.40 \%$ of GBM patients; there are $22.5 \%$ with a MUC16 mutation and other mutations.

Figure 5. MUC16 mutations correlate to biomarkers of good outcome in LGG patients and to biomarkers of bad prognosis in GBM patients. (A) Percent of LGG and GBM patients carrying EGFR, MUC16, PIK3, PTEN, and TP53 classified by IDH1 mutation and/or 1p/19q co-deletion. Most LGG patients with MUC16 mutation have IDH1 mutated and 1p/19q co-deletion that indicates good prognosis. In contrast, all GBM patients with a MUC16 mutation have wild-type IDH1 predictive of aggressive tumors. (B) Graphic of the percentage of primary and recurrent GBM tumors classified according to the gene mutations. Most GBM patients with MUC16 mutation are primary tumors, but mutated MUC16 GBM patients have the second highest percentage of recurrence. (C) Methylation pattern of LGG and GBM patients. All LGG patients with a MUC16 mutation have a MGMT promoter methylation. This generally predicts good prognosis. All GBM patients with mutated MUC16 have non-G-CIMP methylation status that predicts worse outcomes. (D) The percentage of 10q chromosome arm deletion in LGG and GBM patients. An increased percentage of 10q deletions was observed in GBM patients versus LGG patients containing the same mutation status. 10q arm deletion has been correlated to worse prognosis in gliomas. 
medRxiv preprint doi: https://doi.org/10.1101/2022.02.10.22270821; this version posted February 15, 2022. The copyright holder for this preprint (which was not certified by peer review) is the author/funder, who has granted medRxiv a license to display the preprint in

It is made available under a CC-BY-NC-ND 4.0 International license .

\section{REFERENCES}

1. Davis ME. Epidemiology and Overview of Gliomas. Semin Oncol Nurs, 2018, $34: 420-9$

2. Wang TJC, Mehta MP. Low-Grade Glioma Radiotherapy Treatment and Trials. Neurosurg Clin N Am, 2019, 30:111-8

3. Perry A, Wesseling P. Histologic classification of gliomas. Handb Clin Neurol, 2016, 134:71-95

4. Louis DN, Ohgaki H, Wiestler OD, Cavenee WK, Burger PC, Jouvet A, Scheithauer BW, Kleihues P. The 2007 WHO classification of tumours of the central nervous system. Acta Neuropathol, 2007, 114:97-109

5. Youland RS, Schomas DA, Brown PD, Nwachukwu C, Buckner JC, Giannini C, Parney IF, Laack NN. Changes in presentation, treatment, and outcomes of adult low-grade gliomas over the past fifty years. Neuro Oncol, 2013, 15:1102-10

6. Louis DN, Perry A, Reifenberger G, von Deimling A, Figarella-Branger D, Cavenee WK, Ohgaki H, Wiestler OD, Kleihues P, Ellison DW. The 2016 World Health Organization Classification of Tumors of the Central Nervous System: a summary. Acta Neuropathol, 2016, 131:803-20

7. Ferrer VP, Moura Neto V, Mentlein R. Glioma infiltration and extracellular matrix: key players and modulators. Glia, 2018, 66

8. Carballo GB, Ribeiro JH, Lopes GPF, Ferrer VP, Dezonne RS, Pereira CM, Spohr TCLSE. GANT-61 Induces Autophagy and Apoptosis in Glioblastoma Cells despite their heterogeneity. Cell Mol Neurobiol, 2021, 41:1227-44

9. Omuro A, DeAngelis LM. Glioblastoma and other malignant gliomas: A clinical review. JAMA - J Am Med Assoc, 2013, 310:1842-50

10. Pessoa LS, Heringer M, Ferrer VP. ctDNA as a cancer biomarker: A broad overview. Crit Rev Oncol Hematol, 2020, 155

11. Davies JR, Kirkham S, Svitacheva N, Thornton DJ, Carlstedt I. MUC16 is produced in tracheal surface epithelium and submucosal glands and is present in secretions from normal human airway and cultured bronchial epithelial cells. Int $\mathbf{J}$ 
medRxiv preprint doi: https://doi.org/10.1101/2022.02.10.22270821; this version posted February 15, 2022. The copyright holder for this preprint (which was not certified by peer review) is the author/funder, who has granted medRxiv a license to display the preprint in It is made available under a CC-BY-NC-ND 4.0 International license .

Biochem Cell Biol, 2007, 39:1943-54

12. Wang Y, Cheon DJ, Lu Z, Cunningham SL, Chen CM, Luo RZ, Xing D, Orsulic S, Bast RC, Behringer RR. MUC16 expression during embryogenesis, in adult tissues, and ovarian cancer in the mouse. Differentiation, 2008, 76:1081-92

13. Xiong L, Woodward AM, Argüeso P. Notch signaling modulates MUC16 biosynthesis in an in vitro model of human corneal and conjunctival epithelial cell differentiation. Invest Ophthalmol Vis Sci, 2011, 52:5641-6

14. Felder M, Kapur A, Gonzalez-Bosquet J, Horibata S, Heintz J, Albrecht R, Fass L, Kaur J, Hu K, Shojaei H, Whelan RJ, Patankar MS. MUC16 (CA125): Tumor biomarker to cancer therapy, a work in progress. Mol Cancer, 2014, 13:1-15

15. Hattrup CL, Gendler SJ. Structure and function of the cell surface (tethered) mucins. Annu Rev Physiol, 2008, 70:431-57

16. Blalock TD, Spurr-Michaud SJ, Tisdale AS, Gipson IK. Release of membraneassociated mucins from ocular surface epithelia. Invest Ophthalmol Vis Sci, 2008, 49:1864-71

17. Morgado M, Carson DD. PPAR $\gamma$ Modulation of Cytokine-Stimulated MUC16 (CA125) Expression in Breast and Ovarian Cancer-Derived Cells. J Cell Biochem, 2017, 118:163-71

18. Yin BW, Lloyd KO. Molecular cloning of the CA125 ovarian cancer antigen: identification as a new mucin, MUC16. J Biol Chem, 2001, 276:27371-5

19. Haridas D, Ponnusamy MP, Chugh S, Lakshmanan I, Seshacharyulu P, Batra SK. MUC16: molecular analysis and its functional implications in benign and malignant conditions. FASEB J, 2014, 28:4183-99

20. Reinartz S, Failer S, Schuell T, Wagner U. CA125 (MUC16) gene silencing suppresses growth properties of ovarian and breast cancer cells. Eur J Cancer, 2012, 48:1558-69

21. Morgado M, Sutton MN, Simmons M, Warren CR, Lu Z, Constantinou PE, Liu J, Francis LL, Conlan RS, Bast RC, Carson DD. Tumor necrosis factor- $\alpha$ and interferon- $\gamma$ stimulate MUC16 (CA125) expression in breast, endometrial and ovarian cancers through NFkB. Oncotarget, 2016, 7:14871-84 
medRxiv preprint doi: https://doi.org/10.1101/2022.02.10.22270821; this version posted February 15, 2022. The copyright holder for this preprint (which was not certified by peer review) is the author/funder, who has granted medRxiv a license to display the preprint in It is made available under a CC-BY-NC-ND 4.0 International license .

22. Bottoni P, Scatena R. The Role of CA 125 as Tumor Marker: Biochemical and Clinical Aspects. Adv Exp Med Biol, 2015, 867:229-44

23. Zhai Y, Lu Q, Lou T, Cao G, Wang S, Zhang Z. affects the biological functions of ovarian cancer cells and induces an antitumor immune response by activating dendritic cells. Ann Transl Med, 2020, 8:1494

24. Szwedziak K, Szymański D, Strzelczyk J. CA 125 concentration in portal blood as a predictor of resectability in pancreatic tumor. Contemp Oncol (Pozn), 2013, 17:394-9

25. Thomas D, Sagar S, Liu X, Lee HR, Grunkemeyer JA, Grandgenett PM, Caffrey T, O’Connell KA, Swanson B, Marcos-Silva L, Steentoft C, Wandall HH, Maurer HC, Peng XL, Yeh JJ, Qiu F, Yu F, Madiyalakan R, Olive KP, Mandel U, Clausen H, Hollingsworth MA, Radhakrishnan P. Isoforms of MUC16 activate oncogenic signaling through EGF receptors to enhance the progression of pancreatic cancer. Mol Ther, 2021, 29:1557-71

26. Hu J, Sun J. MUC16 mutations improve patients' prognosis by enhancing the infiltration and antitumor immunity of cytotoxic T lymphocytes in the endometrial cancer microenvironment. Oncoimmunology, 2018, 7:e1487914

27. Kanwal M, Ding XJ, Song X, Zhou GB, Cao Y. overexpression induced by gene mutations promotes lung cancer cell growth and invasion. Oncotarget, 2018, 9:12226-39

28. Wang X, Yu X, Krauthammer M, Hugo W, Duan C, Kanetsky PA, Teer JK, Thompson ZJ, Kalos D, Tsai KY, Smalley KSM, Sondak VK, Chen YA, ConejoGarcia JR. The Association of. Cancer Epidemiol Biomarkers Prev, 2020, 29:1792-9

29. Yang Y, Zhang J, Chen Y, Xu R, Zhao Q, Guo W. MUC4, MUC16, and TTN genes mutation correlated with prognosis, and predicted tumor mutation burden and immunotherapy efficacy in gastric cancer and pan-cancer. Clin Transl Med, 2020, 10:e155

30. Aithal A, Rauth S, Kshirsagar P, Shah A, Lakshmanan I, Junker WM, Jain M, Ponnusamy MP, Batra SK. MUC16 as a novel target for cancer therapy. Expert Opin Ther Targets, 2018, 22:675-86 
medRxiv preprint doi: https://doi.org/10.1101/2022.02.10.22270821; this version posted February 15, 2022. The copyright holder for this preprint (which was not certified by peer review) is the author/funder, who has granted medRxiv a license to display the preprint in It is made available under a CC-BY-NC-ND 4.0 International license .

31. Romeijn P, Lenthall R, Stavrou D, Melcher D, Ladyman H, Ritter MA. Identification of glioma-associated antigen MUC 2-63 as CD44. Br J Cancer, 1994, 70:799-803

32. Oosterkamp HM, Scheiner L, Stefanova MC, Lloyd KO, Finstad CL. Comparison of MUC-1 mucin expression in epithelial and non-epithelial cancer cell lines and demonstration of a new short variant form (MUC-1/Z). Int J Cancer, 1997, 72:8794

33. Hagel C, Neumaier M, Stavrou D. Sequencing data of the antiglioma antibody MUC 2-63 and strategy for construction of chimeric antibodies. Cell Biophys, 1994, 24-25:331-9

34. Cerami E, Gao J, Dogrusoz U, Gross BE, Sumer SO, Aksoy BA, Jacobsen A, Byrne CJ, Heuer ML, Larsson E, Antipin Y, Reva B, Goldberg AP, Sander C, Schultz N. The cBio cancer genomics portal: an open platform for exploring multidimensional cancer genomics data. Cancer Discov, 2012, 2:401-4

35. Gao J, Aksoy BA, Dogrusoz U, Dresdner G, Gross B, Sumer SO, Sun Y, Jacobsen A, Sinha R, Larsson E, Cerami E, Sander C, Schultz N. Integrative analysis of complex cancer genomics and clinical profiles using the cBioPortal. Sci Signal, 2013, 6:pl1

36. Hoadley KA, Yau C, Hinoue T, Wolf DM, Lazar AJ, Drill E, Shen R, Taylor AM, Cherniack AD, Thorsson V, Akbani R, Bowlby R, Wong CK, Wiznerowicz M, Sanchez-Vega F, Robertson AG, Schneider BG, Lawrence MS, Noushmehr H, Malta TM, Stuart JM, Benz CC, Laird PW, Network CGA. Cell-of-Origin Patterns Dominate the Molecular Classification of 10,000 Tumors from 33 Types of Cancer. Cell, 2018, 173:291-304.e6

37. Ellrott K, Bailey MH, Saksena G, Covington KR, Kandoth C, Stewart C, Hess J, Ma S, Chiotti KE, McLellan M, Sofia HJ, Hutter C, Getz G, Wheeler D, Ding L, Group MW, Network CGAR. Scalable Open Science Approach for Mutation Calling of Tumor Exomes Using Multiple Genomic Pipelines. Cell Syst, 2018, 6:271-281.e7

38. Taylor AM, Shih J, Ha G, Gao GF, Zhang X, Berger AC, Schumacher SE, Wang C, Hu H, Liu J, Lazar AJ, Cherniack AD, Beroukhim R, Meyerson M, Network 
medRxiv preprint doi: https://doi.org/10.1101/2022.02.10.22270821; this version posted February 15, 2022. The copyright holder for this preprint (which was not certified by peer review) is the author/funder, who has granted medRxiv a license to display the preprint in It is made available under a CC-BY-NC-ND 4.0 International license .

CGAR. Genomic and Functional Approaches to Understanding Cancer Aneuploidy. Cancer Cell, 2018, 33:676-689.e3

39. Liu J, Lichtenberg T, Hoadley KA, Poisson LM, Lazar AJ, Cherniack AD, Kovatich AJ, Benz CC, Levine DA, Lee A V, Omberg L, Wolf DM, Shriver CD, Thorsson V, Hu H, Network CGAR. An Integrated TCGA Pan-Cancer Clinical Data Resource to Drive High-Quality Survival Outcome Analytics. Cell, 2018, 173:400-416.e11

40. Sanchez-Vega F, Mina M, Armenia J, Chatila WK, Luna A, La KC, Dimitriadoy S, Liu DL, Kantheti HS, Saghafinia S, Chakravarty D, Daian F, Gao Q, Bailey MH, Liang WW, Foltz SM, Shmulevich I, Ding L, Heins Z, Ochoa A, Gross B, Gao J, Zhang H, Kundra R, Kandoth C, Bahceci I, Dervishi L, Dogrusoz U, Zhou W, Shen H, Laird PW, Way GP, Greene CS, Liang H, Xiao Y, et al. Oncogenic Signaling Pathways in The Cancer Genome Atlas. Cell, 2018, 173:321-337.e10

41. Gao Q, Liang WW, Foltz SM, Mutharasu G, Jayasinghe RG, Cao S, Liao WW, Reynolds SM, Wyczalkowski MA, Yao L, Yu L, Sun SQ, Chen K, Lazar AJ, Fields RC, Wendl MC, Van Tine BA, Vij R, Chen F, Nykter M, Shmulevich I, Ding L, Group FAW, Network CGAR. Driver Fusions and Their Implications in the Development and Treatment of Human Cancers. Cell Rep, 2018, 23:227-238.e3

42. Bhandari V, Hoey C, Liu LY, Lalonde E, Ray J, Livingstone J, Lesurf R, Shiah YJ, Vujcic T, Huang X, Espiritu SMG, Heisler LE, Yousif F, Huang V, Yamaguchi TN, Yao CQ, Sabelnykova VY, Fraser M, Chua MLK, van der Kwast T, Liu SK, Boutros PC, Bristow RG. Molecular landmarks of tumor hypoxia across cancer types. Nat Genet, 2019, 51:308-18

43. Poore GD, Kopylova E, Zhu Q, Carpenter C, Fraraccio S, Wandro S, Kosciolek T, Janssen S, Metcalf J, Song SJ, Kanbar J, Miller-Montgomery S, Heaton R, Mckay R, Patel SP, Swafford AD, Knight R. Microbiome analyses of blood and tissues suggest cancer diagnostic approach. Nature, 2020, 579:567-74

44. Ding L, Bailey MH, Porta-Pardo E, Thorsson V, Colaprico A, Bertrand D, Gibbs DL, Weerasinghe A, Huang KL, Tokheim C, Cortés-Ciriano I, Jayasinghe R, Chen F, Yu L, Sun S, Olsen C, Kim J, Taylor AM, Cherniack AD, Akbani R, Suphavilai C, Nagarajan N, Stuart JM, Mills GB, Wyczalkowski MA, Vincent BG, Hutter 
CM, Zenklusen JC, Hoadley KA, Wendl MC, Shmulevich L, Lazar AJ, Wheeler DA, Getz G, Network CGAR. Perspective on Oncogenic Processes at the End of the Beginning of Cancer Genomics. Cell, 2018, 173:305-320.e10

45. Bonneville R, Krook MA, Kautto EA, Miya J, Wing MR, Chen HZ, Reeser JW, Yu L, Roychowdhury S. Landscape of Microsatellite Instability Across 39 Cancer Types. JCO Precis Oncol, 2017, 2017

46. Johnson BE, Mazor T, Hong C, Barnes M, Aihara K, McLean CY, Fouse SD, Yamamoto S, Ueda H, Tatsuno K, Asthana S, Jalbert LE, Nelson SJ, Bollen AW, Gustafson WC, Charron E, Weiss WA, Smirnov I V, Song JS, Olshen AB, Cha S, Zhao Y, Moore RA, Mungall AJ, Jones SJM, Hirst M, Marra MA, Saito N, Aburatani H, Mukasa A, Berger MS, Chang SM, Taylor BS, Costello JF. Mutational analysis reveals the origin and therapy-driven evolution of recurrent glioma. Science (80- ), 2014, 343:189-93

47. Ceccarelli M, Barthel FP, Malta TM, Sabedot TS, Salama SR, Murray BA, Morozova O, Newton Y, Radenbaugh A, Pagnotta SM, Anjum S, Wang J, Manyam G, Zoppoli P, Ling S, Rao AA, Grifford M, Cherniack AD, Zhang H, Poisson L, Carlotti CG, Tirapelli DP, Rao A, Mikkelsen T, Lau CC, Yung WK, Rabadan R, Huse J, Brat DJ, Lehman NL, Barnholtz-Sloan JS, Zheng S, Hess K, Rao G, Meyerson M, et al. Molecular Profiling Reveals Biologically Discrete Subsets and Pathways of Progression in Diffuse Glioma. Cell, 2016, 164:550-63

48. Zhao J, Chen AX, Gartrell RD, Silverman AM, Aparicio L, Chu T, Bordbar D, Shan D, Samanamud J, Mahajan A, Filip I, Orenbuch R, Goetz M, Yamaguchi JT, Cloney M, Horbinski C, Lukas R V, Raizer J, Rae AI, Yuan J, Canoll P, Bruce JN, Saenger YM, Sims P, Iwamoto FM, Sonabend AM, Rabadan R. Immune and genomic correlates of response to anti-PD-1 immunotherapy in glioblastoma. Nat Med, 2019, 25:462-9

49. Brennan CW, Verhaak RG, McKenna A, Campos B, Noushmehr H, Salama SR, Zheng S, Chakravarty D, Sanborn JZ, Berman SH, Beroukhim R, Bernard B, Wu CJ, Genovese G, Shmulevich I, Barnholtz-Sloan J, Zou L, Vegesna R, Shukla SA, Ciriello G, Yung WK, Zhang W, Sougnez C, Mikkelsen T, Aldape K, Bigner DD, Van Meir EG, Prados M, Sloan A, Black KL, Eschbacher J, Finocchiaro G, Friedman W, Andrews DW, Guha A, et al. The somatic genomic landscape of 
medRxiv preprint doi: https://doi.org/10.1101/2022.02.10.22270821; this version posted February 15, 2022. The copyright holder for this preprint (which was not certified by peer review) is the author/funder, who has granted medRxiv a license to display the preprint in It is made available under a CC-BY-NC-ND 4.0 International license .

glioblastoma. Cell, 2013, 155:462-77

50. Network CGAR. Comprehensive genomic characterization defines human glioblastoma genes and core pathways. Nature, 2008, 455:1061-8

51. Schwartzbaum JA, Fisher JL, Aldape KD, Wrensch M. Epidemiology and molecular pathology of glioma. Nat Clin Pr Neurol, 2006, 2:494-503; quiz 1 p following 516

52. Alghamri MS, Thalla R, Avvari RP, Dabaja A, Taher A, Zhao L, Ulintz PJ, Castro MG, Lowenstein PR. Tumor mutational burden predicts survival in patients with low-grade gliomas expressing mutated IDH1. Neurooncol Adv, 2020, 2:vdaa042

53. Shergalis A, Bankhead A, Luesakul U, Muangsin N, Neamati N. Current Challenges and Opportunities in Treating Glioblastoma. Pharmacol Rev, 2018, $70: 412-45$

54. Chen R, Smith-Cohn M, Cohen AL, Colman H. Glioma Subclassifications and Their Clinical Significance. Neurotherapeutics, 2017, 14:284-97

55. Brat DJ, Verhaak RG, Aldape KD, Yung WK, Salama SR, Cooper LA, Rheinbay E, Miller CR, Vitucci M, Morozova O, Robertson AG, Noushmehr H, Laird PW, Cherniack AD, Akbani R, Huse JT, Ciriello G, Poisson LM, Barnholtz-Sloan JS, Berger MS, Brennan C, Colen RR, Colman H, Flanders AE, Giannini C, Grifford M, Iavarone A, Jain R, Joseph I, Kim J, Kasaian K, Mikkelsen T, Murray BA, O’Neill BP, Pachter L, et al. Comprehensive, Integrative Genomic Analysis of Diffuse Lower-Grade Gliomas. N Engl J Med, 2015, 372:2481-98

56. Eckel-Passow JE, Lachance DH, Molinaro AM, Walsh KM, Decker PA, Sicotte H, Pekmezci M, Rice T, Kosel ML, Smirnov I V, Sarkar G, Caron AA, Kollmeyer TM, Praska CE, Chada AR, Halder C, Hansen HM, McCoy LS, Bracci PM, Marshall R, Zheng S, Reis GF, Pico AR, O’Neill BP, Buckner JC, Giannini C, Huse JT, Perry A, Tihan T, Berger MS, Chang SM, Prados MD, Wiemels J, Wiencke JK, Wrensch MR, et al. Glioma Groups Based on 1p/19q, IDH, and TERT Promoter Mutations in Tumors. N Engl J Med, 2015, 372:2499-508

57. Fan K, Yang C, Fan Z, Huang Q, Zhang Y, Cheng H, Jin K, Lu Y, Wang Z, Luo G, Yu X, Liu C. MUC16 C terminal-induced secretion of tumor-derived IL-6 contributes to tumor-associated Treg enrichment in pancreatic cancer. Cancer Lett, 
medRxiv preprint doi: https://doi.org/10.1101/2022.02.10.22270821; this version posted February 15, 2022. The copyright holder for this preprint (which was not certified by peer review) is the author/funder, who has granted medRxiv a license to display the preprint in It is made available under a CC-BY-NC-ND 4.0 International license .

2018, 418:167-75

58. Shen H, Guo M, Wang L, Cui X. MUC16 facilitates cervical cancer progression via JAK2/STAT3 phosphorylation-mediated cyclooxygenase-2 expression. Genes Genomics, 2020, 42:127-33

59. Lakshmanan I, Salfity S, Seshacharyulu P, Rachagani S, Thomas A, Das S, Majhi PD, Nimmakayala RK, Vengoji R, Lele SM, Ponnusamy MP, Batra SK, Ganti AK. MUC16 Regulates TSPYL5 for Lung Cancer Cell Growth and Chemoresistance by Suppressing p53. Clin Cancer Res, 2017, 23:3906-17

60. Fan K, Zhang D, Li M, Shen S, Wang J, Ni X, Gong Z, Zheng B, Gao Z, Suo T, Liu H. Carboxyl-terminal polypeptide fragment of MUC16 combing stathmin1 promotes gallbladder cancer cell migration and invasion. Med Oncol, 2020, 37:114

61. Coelho R, Marcos-Silva L, Ricardo S, Ponte F, Costa A, Lopes JM, David L. Peritoneal dissemination of ovarian cancer: role of MUC16-mesothelin interaction and implications for treatment. Expert Rev Anticancer Ther, 2018, 18:177-86

62. Zhang M, Cheng S, Jin Y, Zhao Y, Wang Y. Roles of CA125 in diagnosis, prediction, and oncogenesis of ovarian cancer. Biochim Biophys Acta Rev Cancer, 2021, 1875:188503

63. Kim N, Hong Y, Kwon D, Yoon S. Somatic mutaome profile in human cancer tissues. Genomics Inf, 2013, 11:239-44

64. Ma F, Laster K, Nie W, Liu F, Kim DJ, Lee MH, Bai R, Yang R, Liu K, Dong Z. Heterogeneity Analysis of Esophageal Squamous Cell Carcinoma in Cell Lines, Tumor Tissues and Patient-Derived Xenografts. J Cancer, 2021, 12:3930-44

65. Shimizu A, Hirono S, Tani M, Kawai M, Okada K, Miyazawa M, Kitahata Y, Nakamura Y, Noda T, Yokoyama S, Yamaue H. Coexpression of MUC16 and mesothelin is related to the invasion process in pancreatic ductal adenocarcinoma. Cancer Sci, 2012, 103:739-46

66. Chen SH, Hung WC, Wang P, Paul C, Konstantopoulos K. Mesothelin binding to CA125/MUC16 promotes pancreatic cancer cell motility and invasion via MMP7 activation. Sci Rep, 2013, 3:1870

67. Das S, Rachagani S, Torres-Gonzalez MP, Lakshmanan I, Majhi PD, Smith LM, 
medRxiv preprint doi: https://doi.org/10.1101/2022.02.10.22270821; this version posted February 15, 2022. The copyright holder for this preprint (which was not certified by peer review) is the author/funder, who has granted medRxiv a license to display the preprint in It is made available under a CC-BY-NC-ND 4.0 International license .

Wagner KU, Batra SK. Carboxyl-terminal domain of MUC16 imparts tumorigenic and metastatic functions through nuclear translocation of JAK2 to pancreatic cancer cells. Oncotarget, 2015, 6:5772-87

68. Rao TD, Tian H, Ma X, Yan X, Thapi S, Schultz N, Rosales N, Monette S, Wang A, Hyman DM, Levine DA, Solit D, Spriggs DR. Expression of the CarboxyTerminal Portion of MUC16/CA125 Induces Transformation and Tumor Invasion. PLoS One, 2015, 10:e126633

69. Liang C, Qin Y, Zhang B, Ji S, Shi S, Xu W, Liu J, Xiang J, Liang D, Hu Q, Ni Q, $\mathrm{Xu} \mathrm{J,} \mathrm{Yu} \mathrm{X.} \mathrm{Oncogenic} \mathrm{KRAS} \mathrm{Targets} \mathrm{MUC16/CA125} \mathrm{in} \mathrm{Pancreatic} \mathrm{Ductal}$ Adenocarcinoma. Mol Cancer Res, 2017, 15:201-12

70. Liu J, Li L, Luo N, Liu Q, Liu L, Chen D, Cheng Z, Xi X. Inflammatory signals induce MUC16 expression in ovarian cancer cells via NF- $\kappa B$ activation. Exp Ther Med, 2021, 21:163

71. Kaneko O, Gong L, Zhang J, Hansen JK, Hassan R, Lee B, Ho M. A binding domain on mesothelin for CA125/MUC16. J Biol Chem, 2009, 284:3739-49

72. Yang WB, Li CY. Correlations of MUC15 overexpression with clinicopathological features and prognosis of glioma. J Huazhong Univ Sci Technol Med Sci, 2014, 34:254-9

73. Li W, Wu C, Yao Y, Dong B, Wei Z, Lv X, Zhang J, Xu Y. MUC4 modulates human glioblastoma cell proliferation and invasion by upregulating EGFR expression. Neurosci Lett, 2014, 566:82-7

74. Xiao G, Zhang X, Chen Y, Xia Z, Cao H, Huang J, Cheng Q. Aging-related genes are potential prognostic biomarkers for patients with gliomas. Aging (Albany NY), 2021, 13:13239-63

75. Yang C, Tan Y, Li S, Zhou J, Wang Q, Wang Y, Xie Y, Chen L, Li J, Fang C, Kang C. Genomic landscapes by multiregion sequencing combined with circulation tumor DNA detection contribute to molecular diagnosis in glioblastomas. Aging (Albany NY), 2019, 11:11224-43

76. Zhang L, Han X, Shi Y. Association of MUC16 Mutation With Response to Immune Checkpoint Inhibitors in Solid Tumors. JAMA Netw Open, 2020, 
medRxiv preprint doi: https://doi.org/10.1101/2022.02.10.22270821; this version posted February 15, 2022. The copyright holder for this preprint (which was not certified by peer review) is the author/funder, who has granted medRxiv a license to display the preprint in It is made available under a CC-BY-NC-ND 4.0 International license .

3:e2013201

77. Li X, Pasche B, Zhang W, Chen K. Association of MUC16 Mutation With Tumor Mutation Load and Outcomes in Patients With Gastric Cancer. JAMA Oncol, 2018, 4:1691-8

78. Sun H, Yin L, Li S, Han S, Song G, Liu N, Yan C. Prognostic significance of IDH mutation in adult low-grade gliomas: a meta-analysis. J Neurooncol, 2013, $113: 277-84$

79. Khan I, Waqas M, Shamim MS. Prognostic significance of IDH 1 mutation in patients with glioblastoma multiforme. J Pak Med Assoc, 2017, 67:816-7

80. Wick W, Hartmann C, Engel C, Stoffels M, Felsberg J, Stockhammer F, Sabel MC, Koeppen S, Ketter R, Meyermann R, Rapp M, Meisner C, Kortmann RD, Pietsch T, Wiestler OD, Ernemann U, Bamberg M, Reifenberger G, von Deimling A, Weller M. NOA-04 randomized phase III trial of sequential radiochemotherapy of anaplastic glioma with procarbazine, lomustine, and vincristine or temozolomide. J Clin Oncol, 2009, 27:5874-80

81. Cairncross G, Wang M, Shaw E, Jenkins R, Brachman D, Buckner J, Fink K, Souhami L, Laperriere N, Curran W, Mehta M. Phase III trial of chemoradiotherapy for anaplastic oligodendroglioma: long-term results of RTOG 9402. J Clin Oncol, 2013, 31:337-43

82. van den Bent MJ, Brandes AA, Taphoorn MJ, Kros JM, Kouwenhoven MC, Delattre JY, Bernsen HJ, Frenay M, Tijssen CC, Grisold W, Sipos L, Enting RH, French PJ, Dinjens WN, Vecht CJ, Allgeier A, Lacombe D, Gorlia T, Hoang-Xuan K. Adjuvant procarbazine, lomustine, and vincristine chemotherapy in newly diagnosed anaplastic oligodendroglioma: long-term follow-up of EORTC brain tumor group study 26951. J Clin Oncol, 2013, 31:344-50

83. Lv L, Zhang Y, Zhao Y, Wei Q, Zhao Y, Yi Q. Effects of 1p/19q Codeletion on Immune Phenotype in Low Grade Glioma. Front Cell Neurosci, 2021, 15:1-18

84. Li F, He X, Ye D, Lin Y, Yu H, Yao C, Huang L, Zhang J, Wang F, Xu S, Wu X, Liu L, Yang C, Shi J, Liu J, Qu Y, Guo F, Zhao J, Xu W, Zhao S. NADP(+)-IDH Mutations Promote Hypersuccinylation that Impairs Mitochondria Respiration and Induces Apoptosis Resistance. Mol Cell, 2015, 60:661-75 
medRxiv preprint doi: https://doi.org/10.1101/2022.02.10.22270821; this version posted February 15, 2022. The copyright holder for this preprint (which was not certified by peer review) is the author/funder, who has granted medRxiv a license to display the preprint in It is made available under a CC-BY-NC-ND 4.0 International license .

85. Wang X, Liu R, Qu X, Yu H, Chu H, Zhang Y, Zhu W, Wu X, Gao H, Tao B, Li W, Liang J, Li G, Yang W. $\alpha$-Ketoglutarate-Activated NF-кB Signaling Promotes Compensatory Glucose Uptake and Brain Tumor Development. Mol Cell, 2019, 76:148-162.e7

86. Hegi ME, Diserens AC, Gorlia T, Hamou MF, de Tribolet N, Weller M, Kros JM, Hainfellner JA, Mason W, Mariani L, Bromberg JE, Hau P, Mirimanoff RO, Cairncross JG, Janzer RC, Stupp R. MGMT gene silencing and benefit from temozolomide in glioblastoma. N Engl J Med, 2005, 352:997-1003

87. Wick W, Weller M, van den Bent M, Sanson M, Weiler M, von Deimling A, Plass C, Hegi M, Platten M, Reifenberger G. MGMT testing--the challenges for biomarker-based glioma treatment. Nat Rev Neurol, 2014, 10:372-85

88. Hegi ME, Diserens AC, Godard S, Dietrich PY, Regli L, Ostermann S, Otten P, Van Melle G, de Tribolet N, Stupp R. Clinical trial substantiates the predictive value of O-6-methylguanine-DNA methyltransferase promoter methylation in glioblastoma patients treated with temozolomide. Clin Cancer Res, 2004, 10:18714

89. Fontana L, Tabano S, Bonaparte E, Marfia G, Pesenti C, Falcone R, Augello C, Carlessi N, Silipigni R, Guerneri S, Campanella R, Caroli M, Sirchia SM, Bosari S, Miozzo M. MGMT-Methylated Alleles Are Distributed Heterogeneously Within Glioma Samples Irrespective of IDH Status and Chromosome 10q Deletion. J Neuropathol Exp Neurol, 2016, 75:791-800

90. Stupp R, Hegi ME, Mason WP, van den Bent MJ, Taphoorn MJ, Janzer RC, Ludwin SK, Allgeier A, Fisher B, Belanger K, Hau P, Brandes AA, Gijtenbeek J, Marosi C, Vecht CJ, Mokhtari K, Wesseling P, Villa S, Eisenhauer E, Gorlia T, Weller M, Lacombe D, Cairncross JG, Mirimanoff RO, Groups EO for R, of Cancer Brain Tumour T, Oncology R, Group NCI of CCT. Effects of radiotherapy with concomitant and adjuvant temozolomide versus radiotherapy alone on survival in glioblastoma in a randomised phase III study: 5-year analysis of the EORTC-NCIC trial. Lancet Oncol, 2009, 10:459-66

91. van Thuijl HF, Scheinin I, Sie D, Alentorn A, van Essen HF, Cordes M, Fleischeuer R, Gijtenbeek AM, Beute G, van den Brink WA, Meijer GA, Havenith 
M, Idbaih A, Hoang-Xuan K, Mokhtari K, Verhaak RG, van der Valk P, van de Wiel MA, Heimans JJ, Aronica E, Reijneveld JC, Wesseling P, Ylstra B. Spatial and temporal evolution of distal 10q deletion, a prognostically unfavorable event in diffuse low-grade gliomas. Genome Biol, 2014, 15:471

92. Sanson M, Leuraud P, Aguirre-Cruz L, He J, Marie Y, Cartalat-Carel S, Mokhtari K, Duffau H, Delattre JY, Hoang-Xuan K. Analysis of loss of chromosome 10q, DMBT1 homozygous deletions, and PTEN mutations in oligodendrogliomas. J Neurosurg, 2002, 97:1397-401

93. Fontana L, Tabano S, Bonaparte E, Marfia G, Pesenti C, Falcone R, Augello C, Carlessi N, Silipigni R, Guerneri S, Campanella R, Caroli M, Sirchia SM, Bosari S, Miozzo M. MGMT-methylated alleles are distributed heterogeneously within glioma samples irrespective of IDH Status and chromosome 10q Deletion. J Neuropathol Exp Neurol, 2016, 75:791-800

94. Bhatia R, Gautam SK, Cannon A, Thompson C, Hall BR, Aithal A, Banerjee K, Jain M, Solheim JC, Kumar S, Batra SK. Cancer-associated mucins: role in immune modulation and metastasis. Cancer Metastasis Rev, 2019, 38:223-36

95. Kui Wong N, Easton RL, Panico M, Sutton-Smith M, Morrison JC, Lattanzio FA, Morris HR, Clark GF, Dell A, Patankar MS. Characterization of the oligosaccharides associated with the human ovarian tumor marker CA125. J Biol Chem, 2003, 278:28619-34

96. Angata T, Varki A. Siglec-7: a sialic acid-binding lectin of the immunoglobulin superfamily. Glycobiology, 2000, 10:431-8

97. Zhang JQ, Nicoll G, Jones C, Crocker PR. Siglec-9, a novel sialic acid binding member of the immunoglobulin superfamily expressed broadly on human blood leukocytes. J Biol Chem, 2000, 275:22121-6

98. Allavena P, Chieppa M, Bianchi G, Solinas G, Fabbri M, Laskarin G, Mantovani A. Engagement of the mannose receptor by tumoral mucins activates an immune suppressive phenotype in human tumor-associated macrophages. Clin Dev Immunol, 2010, 2010:547179

99. Comamala M, Pinard M, Thériault C, Matte I, Albert A, Boivin M, Beaudin J, Piché A, Rancourt C. Downregulation of cell surface CA125/MUC16 induces 
medRxiv preprint doi: https://doi.org/10.1101/2022.02.10.22270821; this version posted February 15, 2022. The copyright holder for this preprint (which was not certified by peer review) is the author/funder, who has granted medRxiv a license to display the preprint in It is made available under a CC-BY-NC-ND 4.0 International license .

epithelial-to-mesenchymal transition and restores EGFR signalling in NIH:OVCAR3 ovarian carcinoma cells. Br J Cancer, 2011, 104:989-99

100. Larkin J, Chiarion-Sileni V, Gonzalez R, Grob JJ, Rutkowski P, Lao CD, Cowey CL, Schadendorf D, Wagstaff J, Dummer R, Ferrucci PF, Smylie M, Hogg D, Hill A, Márquez-Rodas I, Haanen J, Guidoboni M, Maio M, Schöffski P, Carlino MS, Lebbé C, McArthur G, Ascierto PA, Daniels GA, Long G V, Bastholt L, Rizzo JI, Balogh A, Moshyk A, Hodi FS, Wolchok JD. Five-Year Survival with Combined Nivolumab and Ipilimumab in Advanced Melanoma. N Engl J Med, 2019, $381: 1535-46$

101. Paz-Ares L, Luft A, Vicente D, Tafreshi A, Gümüş M, Mazières J, Hermes B, Çay Şenler F, Csőszi T, Fülöp A, Rodríguez-Cid J, Wilson J, Sugawara S, Kato T, Lee KH, Cheng Y, Novello S, Halmos B, Li X, Lubiniecki GM, Piperdi B, Kowalski DM, Investigators K-407. Pembrolizumab plus Chemotherapy for Squamous NonSmall-Cell Lung Cancer. N Engl J Med, 2018, 379:2040-51

102. Zhao F, Xu N, Yang J, Li B, Shi J, Zheng Y, Xu L. Identification of an immune subtype predicting survival risk and immune activity in hepatocellular carcinoma. Aging (Albany NY), 2021, 13

103. Zhang L, Han X, Shi Y. Association of MUC16 Mutation with Response to Immune Checkpoint Inhibitors in Solid Tumors. JAMA Netw Open, 2020, 3:1-12

104. Pandey K, Lee E, Park N, Hur J, Cho YB, Katuwal NB, Kim SK, Lee SA, Kim I, An HJ, Hwang S, Moon YW. Deregulated Immune Pathway Associated with Palbociclib Resistance in Preclinical Breast Cancer Models: Integrative Genomics and Transcriptomics. Genes (Basel), 2021, 12

105. Filley AC, Henriquez M, Dey M. Recurrent glioma clinical trial, CheckMate-143: the game is not over yet. Oncotarget, 2017, 8:91779-94 
medRxiv preprint doi: https://doi.org/10.1101/2022.02.10.22270821; this version posted February 15, 2022. The copyright holder for this preprint (which was not certified by peer review) is the author/funder, who has granted medRxiv a license to display the preprint in It is made available under a CC-BY-NC-ND 4.0 International license .

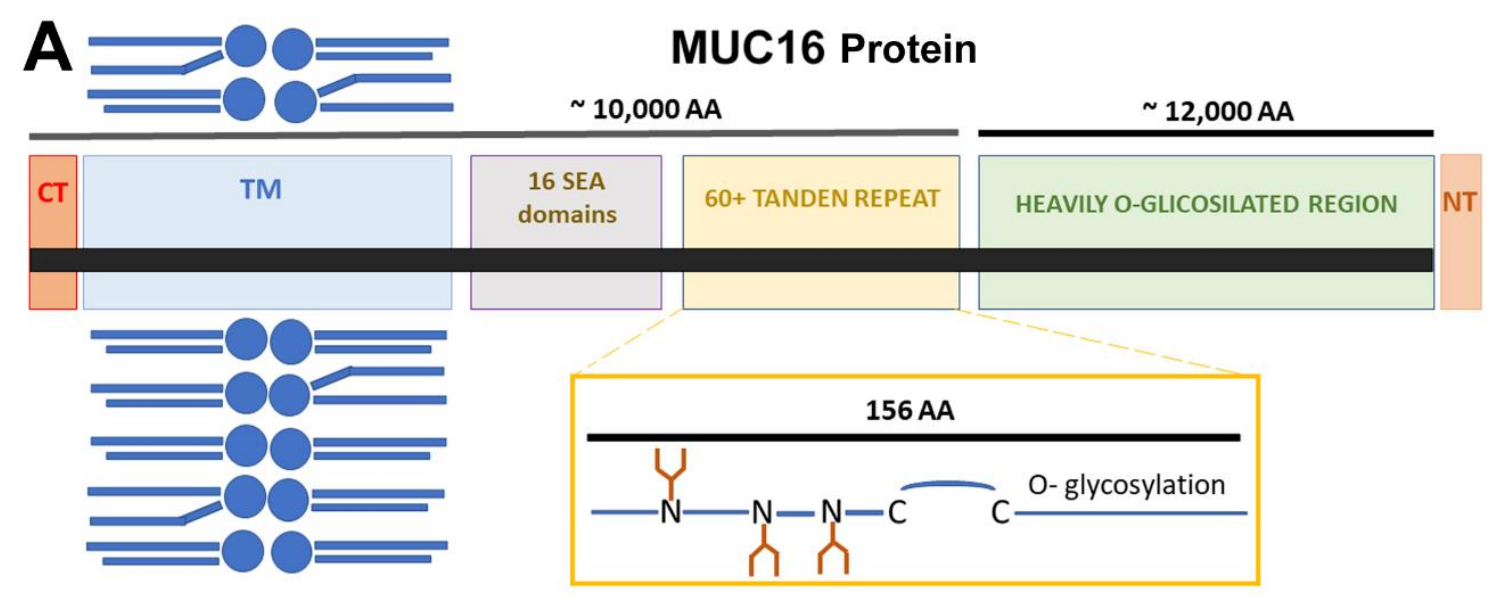

B

MUC16 Gene

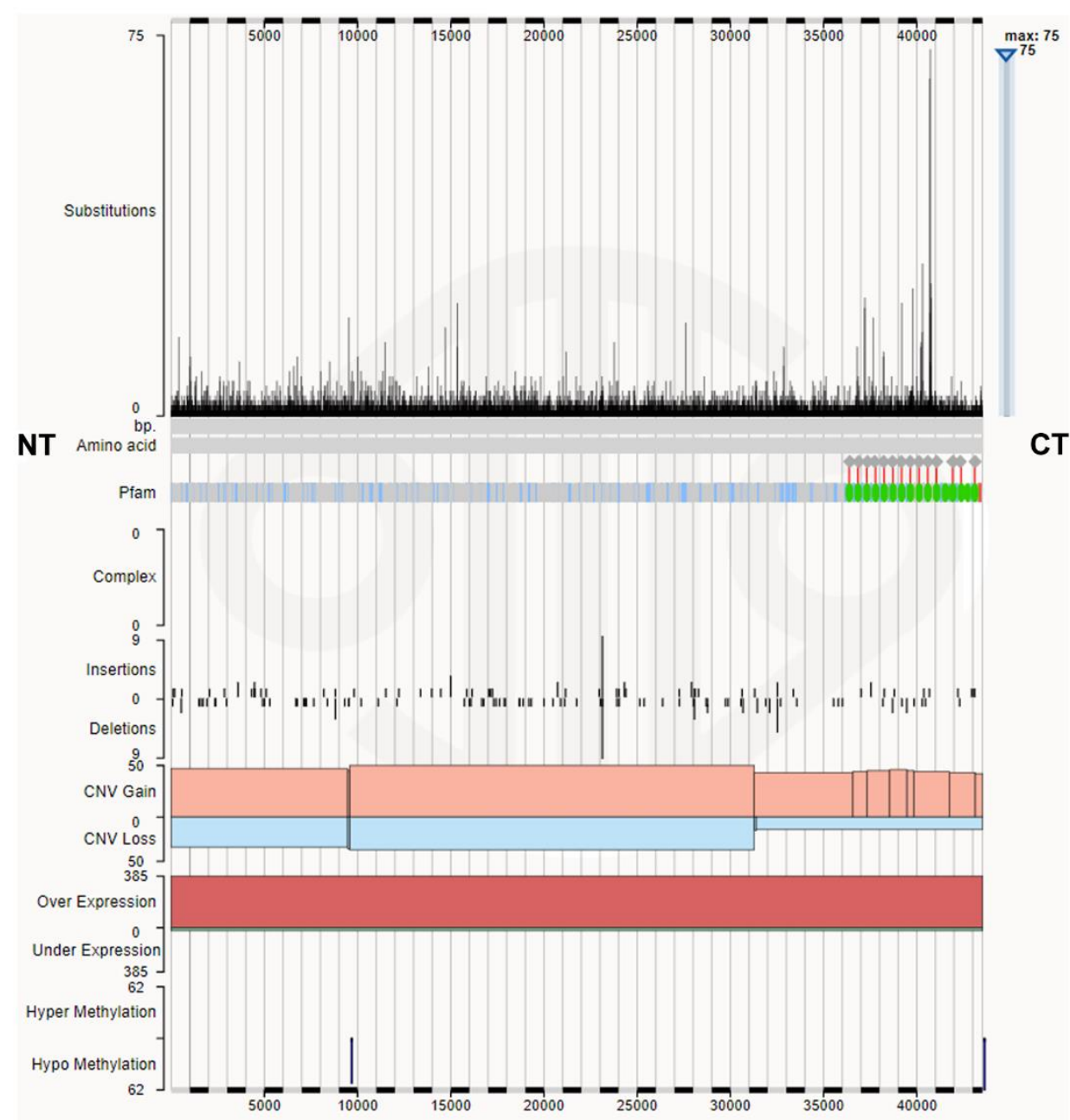

Figure 1 
medRxiv preprint doi: $h$ ttps://doi.org/10.1101/2022.02.10.22270821; this version posted February 15, 2022. The copyright holder for this preprint (which was not certified by peer review) is the author/funder, who has granted medRxiv a license to display the preprint in It is made available under a CC-BY-NC-ND 4.0 International license

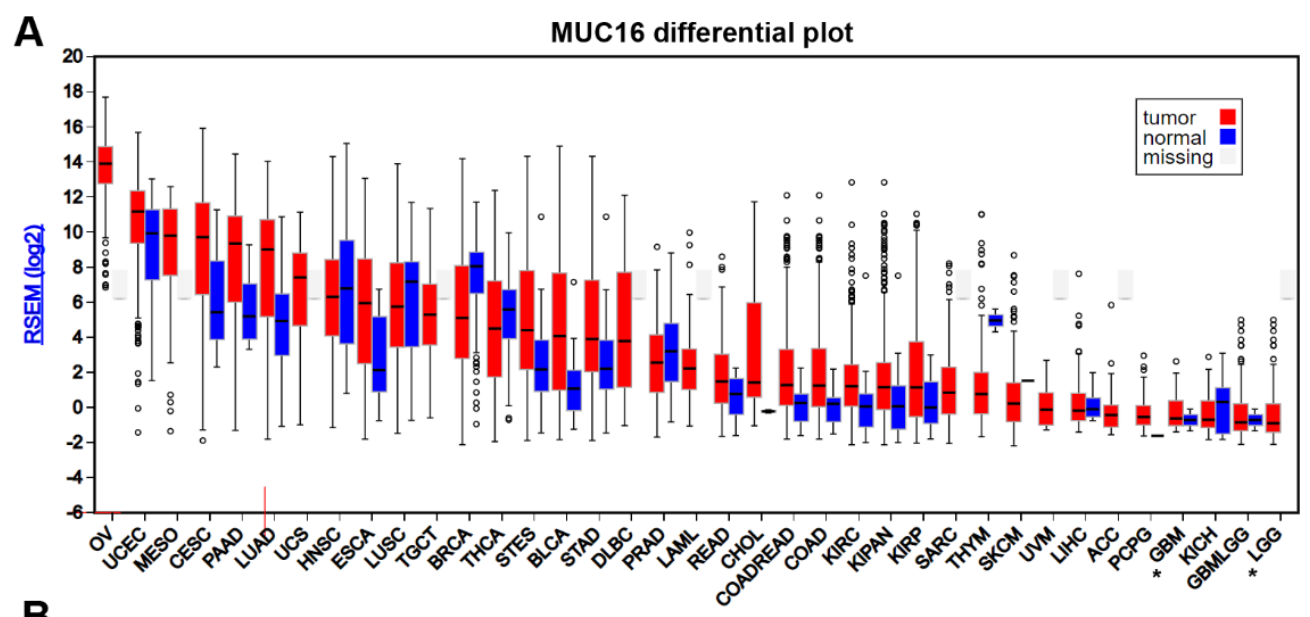

\section{B}

Mutated Genes (848 profiled LGG samples)

Mutated Genes (520 profiled GBM samples)

\begin{tabular}{|c|c|c|c|c|c|c|c|}
\hline Gene & \#Mut & $\#$ & Freq & Gene & \#Mut & \# & Freq \\
\hline IDH1 & 664 & 664 & $78.3 \%$ & PTEN & 175 & 168 & $32.3 \%$ \\
\hline TP53 & 556 & 438 & $51.7 \%$ & TP53 & 190 & 159 & $30.6 \%$ \\
\hline ATRX & 390 & 350 & $41.3 \%$ & TTN & 202 & 101 & $25.4 \%$ \\
CIC & 198 & 165 & $19.5 \%$ & EGFR & 133 & 110 & $21.2 \%$ \\
TTN & 145 & 89 & $11.1 \%$ & MUC16 & 106 & 64 & $14.9 \%$ \\
FUBP1 & 76 & 73 & $9.1 \%$ & FLG & 71 & 54 & $13.6 \%$ \\
\hline NCOA6 & 4 & 4 & $8.3 \%$ & NF1 & 87 & 62 & $11.9 \%$ \\
\hline RPL21 & 4 & 4 & $8.3 \%$ & RYR2 & 58 & 47 & $11.0 \%$ \\
\hline OR10AG1 & 4 & 4 & $8.3 \%$ & PIK3R1 & 50 & 48 & $9.8 \%$ \\
\hline ZKSCAN4 & 4 & 4 & $8.3 \%$ & SPTA1 & 45 & 38 & \\
\hline MUC16 & 73 & 53 & $6.3 \%$ & & & & $9.6 \%$ \\
\hline
\end{tabular}

Figure 2

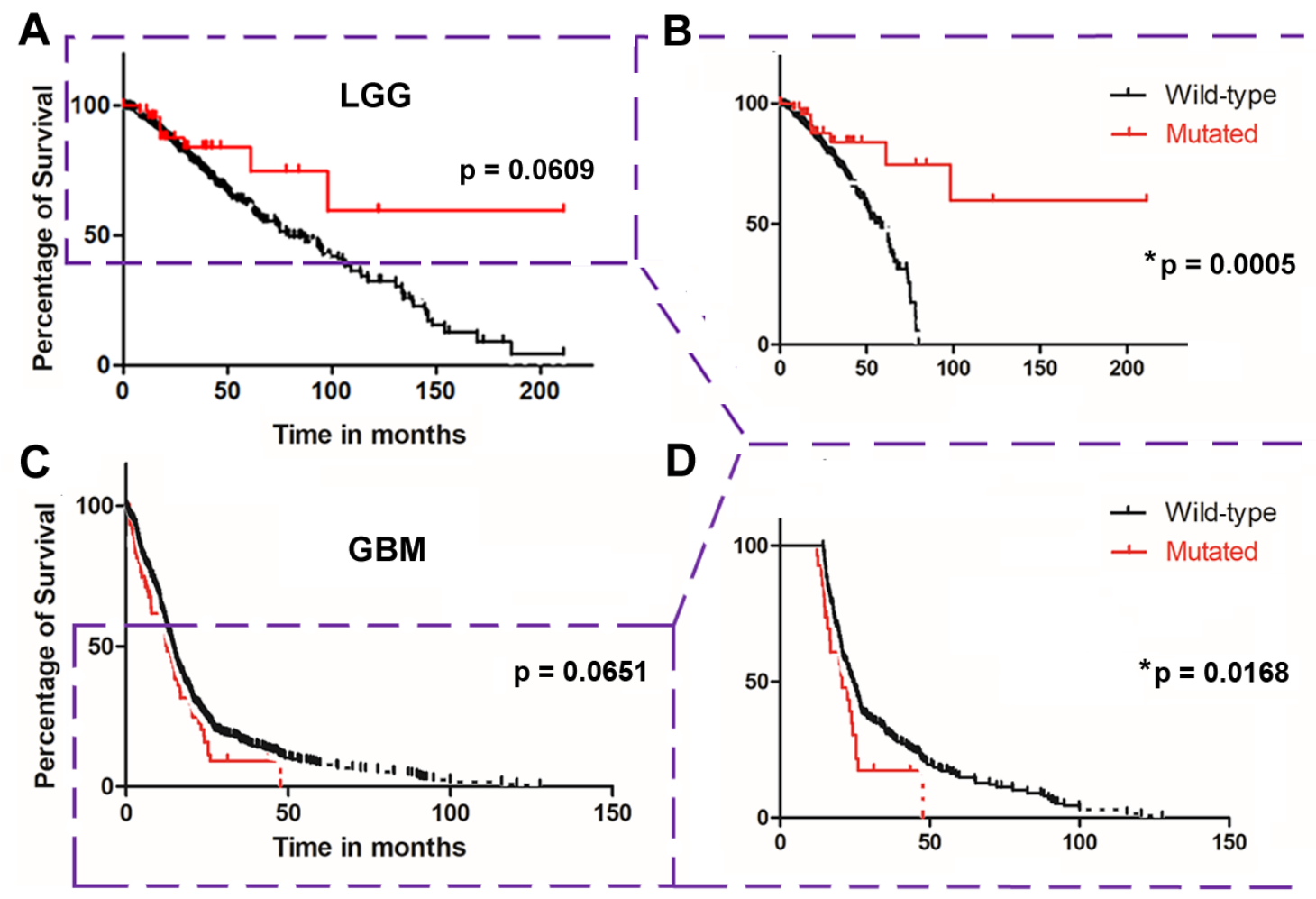

Figure 3 
medRxiv preprint doi: https://doi.org/10.1101/2022.02.10.22270821; this version posted February 15, 2022. The copyright holder for this preprint (which was not certified by peer review) is the author/funder, who has granted medRxiv a license to display the preprint in It is made available under a CC-BY-NC-ND 4.0 International license

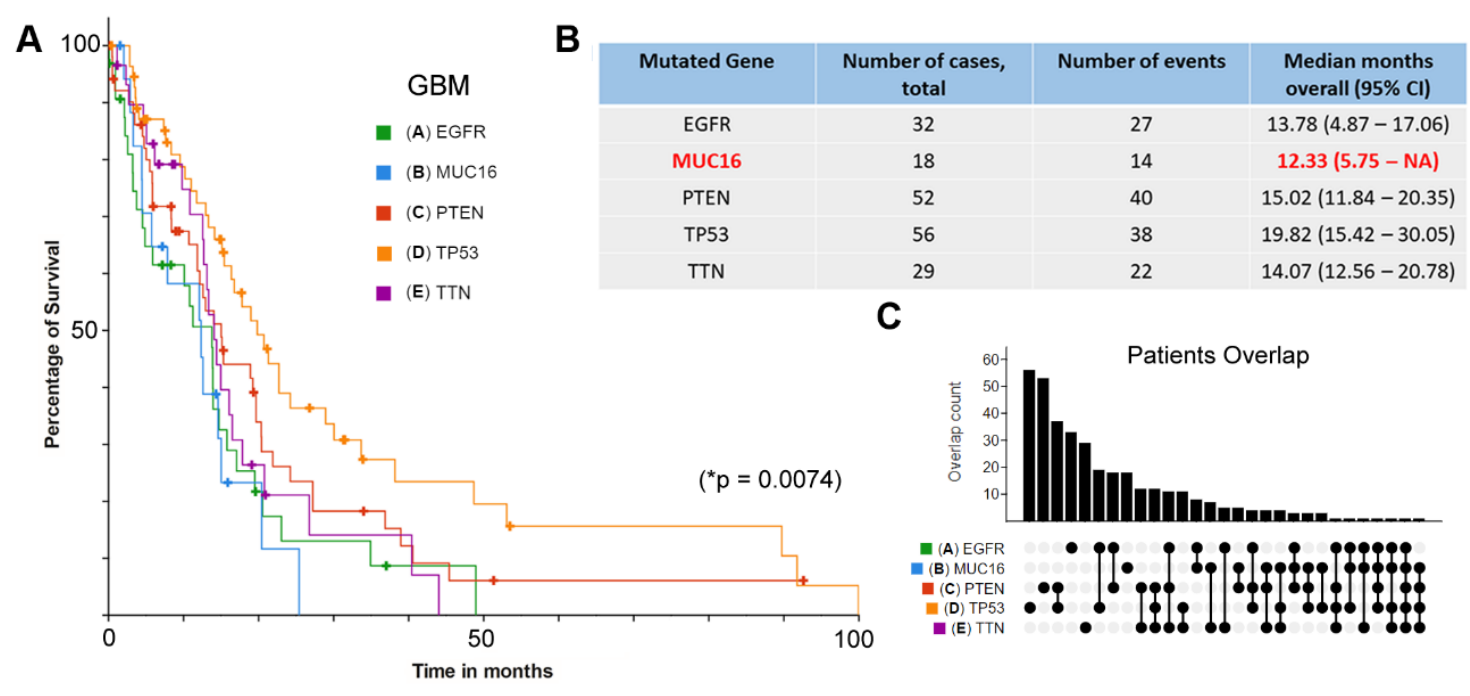

\section{Figure 4}

A

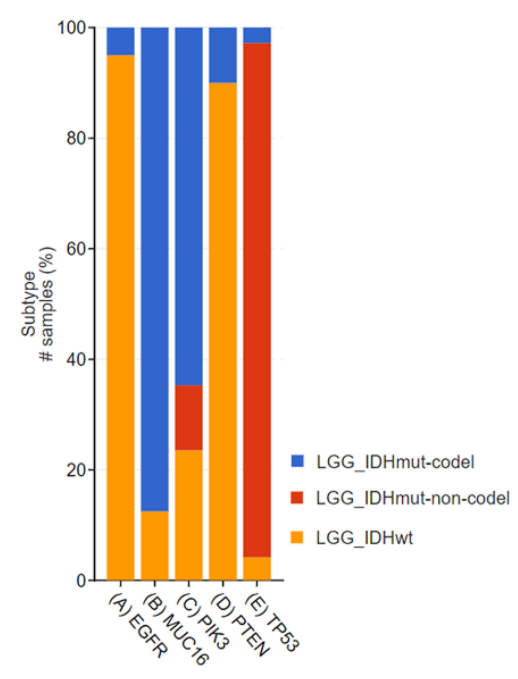

C

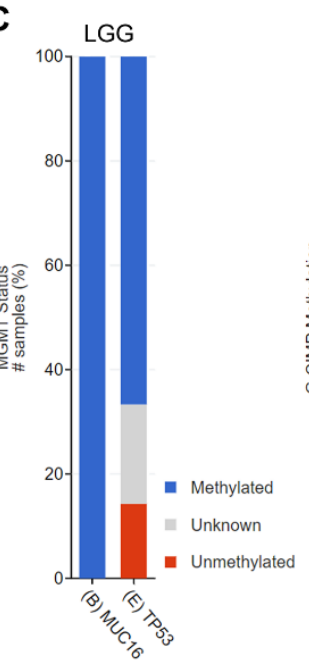

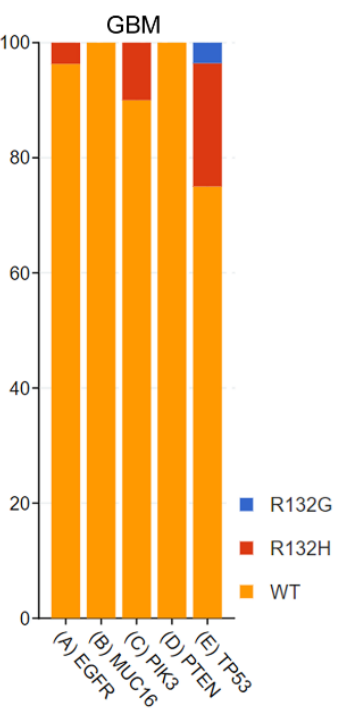

B

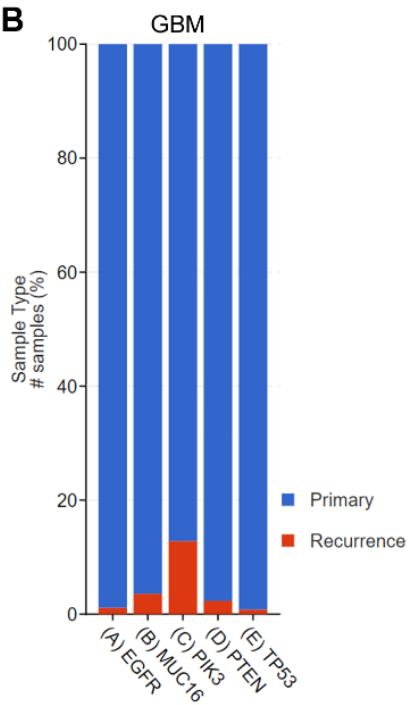

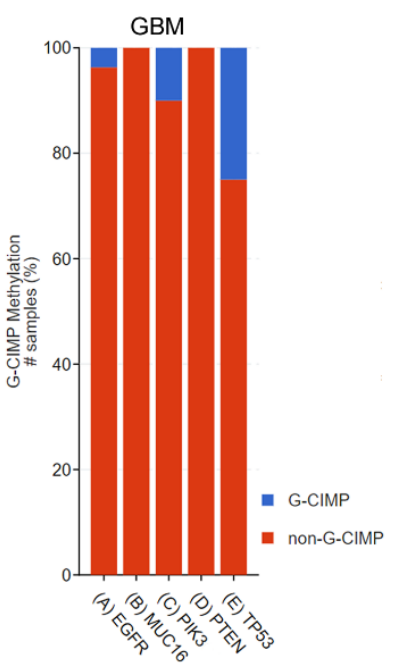

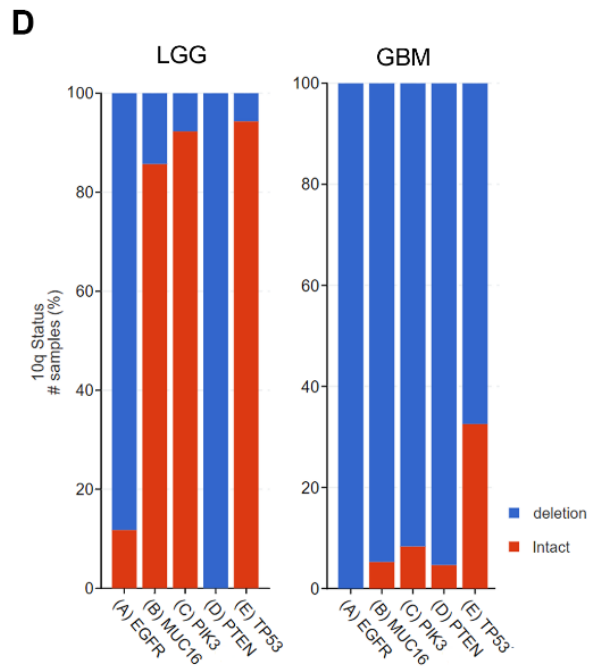

Figure 5 